Goldschmidt 2021 Abstract

https://doi.org/10.7185/gold2021.5872

\section{Vectoring lithium (Li) mineralizations: a first approach to pegmatite geochemical halo definition in the Fregeneda-Almendra area}

\author{
JOANA CARDOSO-FERNANDES ${ }^{1,2}$, ALEXANDRE \\ LIMA $^{2}$, ENCARNACIÓN RODA-ROBLES ${ }^{3}$, MARIA DOS \\ ANJOS RIBEIRO $^{1,2}$ AND ANA C. TEODORO ${ }^{1,2}$
}

${ }^{1}$ Department of Geosciences, Environment and Spatial

Plannings, Faculty of Sciences, University of Porto

${ }^{2}$ ICT (Institute of Earth Sciences) - Porto pole

${ }^{3}$ Departamento de Geología, Universidad del País Vasco (UPV/EHU)

Presenting Author: joana.fernandes@fc.up.pt

\section{Background and study area}

Previous studies have focused on the development of innovative exploration techniques [1] for critical metals like Li (key to the electrification of vehicles and energy storage). However, most of these techniques can only detect surface pegmatite-hosted deposits. In this study, a first attempt is made to define the geochemical halos associated with different types of pegmatites in the Fregeneda-Almendra (Spain-Portugal) pegmatite field. Excluding intra-granitic pegmatites, the remaining metasediment-hosted dykes range from simple, concordant, barren pegmatites to more evolved, Li, F, Sn, Rb, $\mathrm{Nb}>\mathrm{Ta}, \mathrm{B}$, and $\mathrm{P}$ enriched dykes. The host-rocks correspond to a Neoproterozoic-Cambrian pelitic-sandy flysch series.

\section{Approach and preliminary results}

Samples were collected transverse to both mineralized and barren dykes. The process included both surface and drill core host-rock samples, besides control samples collected outside pegmatite influence. Major and trace elements were analyzed by ICP-OES/ICP-MS. Scatterplots and Pearson's coefficient analysis highlighted a strong correlation between $\mathrm{Li}$ and $\mathrm{Tl}$ and $\mathrm{Rb}$, as well as a moderate correlation with $\mathrm{Sn}$ and Cs - Figure 1 . A very strong correlation between $\mathrm{Tl}$ and $\mathrm{Rb}$ was observed. Both host-rocks of barren and Li-bearing dykes showed enrichment in $\mathrm{Li}, \mathrm{Cs}$ and $\mathrm{Rb}$ when compared with the control group, but the degree of enrichment in Cs increases with the evolution degree of the pegmatites. Field observations point to B metasomatism in the host-rock of both barren and evolved dykes that can reach up to $30 \mathrm{~m}$ away from the contact of thickest pegmatites.

Figure 1: Scatterplots and Pearson coefficient (r) for selected elements.

\section{Final remarks}

The results showed that geochemical analysis of metasedimentary host-rocks can help to vector possible buried pegmatites. The Cs content might enable the discrimination between barren and Li-bearing dykes. Future work will include detailed lithological and mineral-chemistry studies.

\section{Acknowledgments}

The work was financially supported by FCT with the ERAMIN/0001/2017-LIGHTS and UIDB/04683/2020-ICT projects, and through Ph.D. Thesis, ref. SFRH/BD/136108/2018 (ESF,
NORTE2020); and by Spanish Ministerio de Ciencia, Innovacion y Universidades (Project RTI2018-094097-B-100, with ERDF funds).

[1] Cardoso-Fernandes, J., et al., Detecting Lithium (Li) Mineralizations from Space: Current Research and Future Perspectives. Applied Sciences, 2020. 10(5): p. 1785.

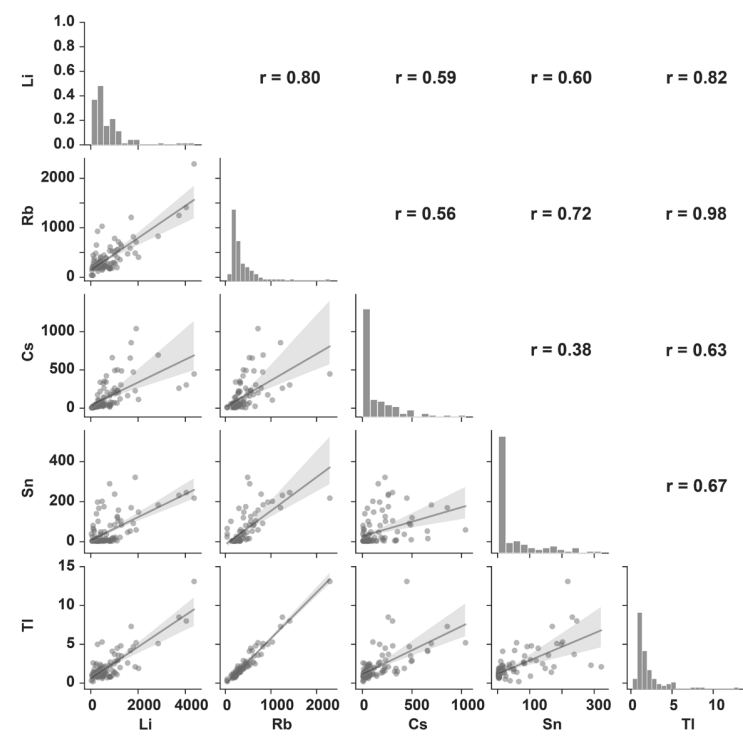

